УДК - 822.11-266

https://doi.org/10.31548/philolog2021.02.093

\title{
ГІПЕРО-ГІПОНІМІЧНІ ЗВ'ЯЗКИ АНГЛОМОВНИХ ТЕРМІНІВ НА ПОЗНАЧЕННЯ ХВОРОБ ТВАРИН
}

\author{
Ю. Г. РОЖКОВ, асистент, \\ Національний університет біоресурсів і природокористування України \\ E-mail: yuriev694@gmail.com \\ https://orcid.org/0000-0002-6830-9130
}

\begin{abstract}
Анотація. Стаття присвячена вивченню специфіки ієрархічної структури англомовних термінів на позначення хвороб тварин на основі гіперо-гіпонімічних відношень та визначенню низки мовних засобів для їх вираження.

Для дослідження структури термінів використовувався компонентний та дистрибутивний аналіз. Для встановлення смислових зв'язків слів використовується лексикографрічний аналіз, що базується на принципі використання словникових тлумачень, які у більшості випадків $\epsilon$ надійним джерелом виділення тематичних груп термінологічних одиниць. Для виявлення системних мовних відношень у досліджуваній терміносистемі використовуємо дистрибутивний аналіз та метод семантичних опозицій.

Побудова ієрархічної структури термінів на позначення хвороб тварин здійснювалася шляхом аналізу відношення між терміном, що позначає загальне родове поняття, $i$ терміном, що відображає видові варіанти того ж поняття.

У термінології на позначення хвороб тварин було виділено два напрями формування термінів: дифреренціація за місцем ураження та за видами тварин.

Встановлено, що аналізована родо-видова структура термінів має багаторівневу організацію, що віддзеркалює еволюцію розвитку иієї клінічної галузі ветеринарної медицини. Структурний аналіз ієрархічної організації термінів на позначення хвороб тварин в англійській мові дозволяє не тільки мати уявлення про зміст цієї предметної галузі, а й краще зрозуміти принципи формування галузевої термінології, що має велике значення для лексикографрічної та перекладацької практики. Терміни на позначення хвороб тварин показують взаємозв'язки явищ, процесів, предметів, що відповідають цій сорері роботи лікарів-ветеринарів, $і$ їх впорядкування можна досягти завдяки правильній класифікації реалій, з яких створюються терміни на основі виділення родових і видових явищ. Отже, виражається закономірність участі термінологічних одиниць у сталих системних відношеннях субординації, які характерні для процесів інтеграції або диференціації їх компонентів як на різних, так і на одному рівні їх виявлення.
\end{abstract}

Ключові слова: гіперо-гіпонімічні відношення, термінологія, хвороби тварин, ветеринарна медицина, структурний аналіз, семантичний аналіз.

Актуальність дослідження. Ветеринарна термінологія $\epsilon$ одним зі специфічних пластів лексики, В силу особливостей структурносемантичного, словотвірного і стилістичного характеру відрізняється від загальновживаних слів i, тим самим, посідає особливе місце в лексичній системі мови.

Дослідженню ветеринарної термінології в англійській мові присвячено багато наукових робіт. Так, епоніми у ветеринарній медицині англійською мовою та джерела ветеринарної термінології досліджувала Л. Комарова [2, 3], сучасним ветеринарно-медичним термінам як презентантам анатомічної номенклатури присвячена робота І. Вакулик [1], термінологічні скорочення в оригінальних текстах англійською мовою 3 ветеринарної медицини були предметом досліджень С. Яковлєвої [14], Ю. Рожков вивчав лінгвістичні та екстралінгвістичні чинники формування англомовного термінологічного поля «хвороби тварин», метонімічні транспозиції та процеси метафоризації в ньому [6, 7, 8], репрезентації категорій часу i простору в англійській термінології ветеринарної медицини присвячено дослідження О. Сиротіної [9], в лінгвістичних студіях Ю. Тімкіної [11] та Л. Ягенич [14] представлено класифікацію ветеринарної термінології в англійській мові та англомовні лексико-граматичні одиниці галузі «Ветеринарія» [10], Т. Череповська та О. Бінкевич вивчали морфологічні особливості ветеринарної термінології [13].

Мовознавцями виконано цілий ряд досліджень ветеринарної термінології, що визначають іiі основні характеристики. Незважаючи на велику кількість праць, присвячених ветеринарній термінології, у вітчизняній та закордонній літературі англійська термінологія ветеринарної медицини не отримала достатнього висвітлення гіперо-гіпонімічних відносин, 
виявлення та опису термінотворчих одиниць i способів, що служать для реалізації явищ гіперо-гіпонімії в корпусі термінів на позначення хвороб тварин. Вивчення і порівняльний аналіз парадигматичних відношень, які виникають при гіперо-гіпонімії в термінології на позначення хвороб тварин пояснюється необхідністю аналізу закономірностей процесів і впорядкування цієї термінології.

Аналіз досліджень і публікацій. Поняття кожної предметної галузі, що знаходяться у взаємних зв'язках, утворюють понятійну систему певної науки. Взаємозв'язок та залежність спеціальних понять часто проявляється у родо-видових відношеннях. Структури, побудовані на відношеннях гіперогіпонімії між професійними поняттями, $\epsilon$ складним каркасом термінології. Взаємні відношення між окремими мовними одиницями та між їх об'єднаннями залежать від положень термінів стосовно один одного.

Вивчення процесів формування гіперогіпонімічних відносин $€$ однією 3 центральних проблем когнітивної семантики, оскільки категоризація безпосередньо пов'язана 3 глобальною проблемою теоретичної лінгвістики в співвідношенні когнітивних i мовних структур.

У кінці XX і на початку XXI століття багато робіт учених (Brighton Laurel J., Alexander Dhoest, Frank W.D. Roder, J. Lyons, Н. Д. Арутюнова, С. В. Гриньов-Гриневич) було присвячено проблематиці парадигматичних відношень, зокрема, вивченню гіперогіпонімічних категорій.

Про актуальність дослідження цієї проблеми свідчать роботи відомих лінгвістівкогнітологів Дж. Лакофффа, Р. Лангакера, л. Талмі, М. Філлмора, Е. Рош, Р. Джекендоффра, О. Кубрякової, В. Дем'янкова, Н. Болдирєва, 3. Попової, Й. Стерніна, В. Новодранової та ін.

Мета статті - вивчити специфріку ієрархічної структури термінів на позначення хвороб тварин на основі гіперо-гіпонімічних відношень і визначити набір мовних засобів для їх вираження.

\section{Матеріали і методи дослідження.} Джерельною базою роботи слугувала картотека 31050 термінів, відібраних 3 англомовних ветеринарних лексикографічних джерел. Для дослідження структури термінів використовуються компонентний та дистрибутивний аналіз. Для встановлення смислових зв'язків слів використовується лексикографічний аналіз, що базується на принципі використання словникових тлумачень, які у більшості випадків є надійним джерелом виділення тематичних груп термінологічних одиниць. Для виявлення системних мовних відношень у досліджуваній терміносистемі використовуємо дистрибутивний аналіз та метод семантичних опозицій.

Результати. Багаторівневі ієрархічні структури, побудовані на відношеннях гіперогіпонімії між професійними поняттями, являють собою складний каркас термінологічної лексики. Взаємні відношення в ієрархії між окремими мовними одиницями та між їх об'єднаннями залежать від взаємопов'язаних положень термінів по відношенню один до одного.

Гіперонім являє собою найменування родового поняття, що характеризується загальними важливими якостями, тоді як видові поняття представлені гіпонімами найменуваннями видового поняття, які можуть включати в себе більшу кількість компонентів.

Більшість термінів на позначення хвороб тварин, поєднаних формально-семантичними гіпонімічними відношеннями, фрормуються на основі приєднання до гіпероніма одного або декількох узгоджених і неузгоджених визначень, виражених іменниками. Наприклад, в англійській мові термін "disease" $€$ родовим (гіперонімом) до ряду типів хвороб, що входять до терміносистеми «хвороби тварин»: Bovine diseases - хвороби жуйних; avian diseases хвороби птиць; sheep and goat diseases (хвороби овець та кіз); equine diseases (хвороби коней); swine diseases (хвороби свиней); bees diseases (хвороби бджіл); multiple species diseases (хвороби різних видів тварин) [5, с. 49].

Відношення гіперо-гіпонімії пронизують усю ієрархічну структуру термінів на позначення хвороб тварин. В основі будь-якої термінологічної системи лежить родо-видовий принцип. Гіпонімія вважається «категоріальним відношенням лексичних одиниць, які базуються на логіко-семантичній субординації» [4, с. 66]. Гіпоніми мають такі властивості:

1) гіпоніми визначаються в термінах шляхом односторонньої імплікації;

2) значення гіпоніму семантично складніше, повніше, ніж у гіпероніма;

3) семантичні відношення гіпонімів - це відношення елементів одного класу.

Гіпоніми містять смисловий зміст гіпероніма і протиставляються один одному відповідними додатковими диференціальними семами.

Терміни вступають у родо-видові відношення, залишаючись гіпонімами один стосовно іншого. Терміни на позначення хвороб тварин, об'єднані семантичними гіпонімічними відношеннями, формуються на основі приєднання до гіпероніма одного або декількох узгоджених і неузгоджених визначень, виражених іменниками або прикметниками.

Побудова ієрархічної структури термінів на позначення хвороб тварин здійснювалася шляхом 
аналізу відношення між терміном, що позначає загальне родове поняття, і терміном, що відображає видові варіанти того ж поняття. Подібні терміни утворюють ієрархію, яка будується на послідовному підпорядкуванні, наприклад: infectious diseases/iнфекційні захворювання (гіперонім) - Lyme disease/хвороба Лайма; Rabies / сказ; Leptospirosis / лептоспіроз; Canine hepatosoonosis / гепатосооноз собак; Canine skin pythiosis / шкірний пітіоз собак (гіпоніми); cattle diseases / хвороби великої рогатої худоби (гіперонім) - Theileriosis / тейлеріоз; Bovine tuberculosis / туберкульоз жуйних; Bovine babesiosis / бабезіоз жуйних; Bovine brucellosis / бруцельоз жуйних; Dermatophilosis / дерматофрільоз (гіпоніми).

У термінології на позначення хвороб тварин можна виділити два напрями формування термінів: диференціація за місцем ураження та за видами тварин.

Гіперонім Diseases by location (хвороби за місцем ураження) є родовим стосовно інших термінів, що входять у його групу: endocrine and metabolic diseases (ендокринні i метаболічні хвороби); hematology, oncology and immunology (гематологія, онкологія та імунологія); dermatological diseases (дерматологічні захворювання) diseases of gastrointestinal tract (захворювання шлунковокишкового тракту); cardiac and respiratory diseases (кардіореспіраторні захворювання); diseases of urinary ways (захворювання сечовивідних шляхів); diseases of reproductive system (захворювання репродуктивної системи); neurologic and musculoskeletal disorders (неврологічні та скелетно-м'язові порушення) ophthalmological diseases (офтальмологічні захворювання).

Водночас у кожному гіперонімі можна виділити ряд гіпонімів, які представлені у вигляді структури термінології на позначення хвороб тварин:

1. Infectious diseases (інфекційні захворювання): sepsis / сепсис; Feline leukemia virus / вірус лейкемії кішок; Feline immunodeficiency virus / вірус імунодефіциту кішок; Feline infectious peritonitis / інфекційний перитоніт кішок; Lyme disease / хвороба Лайма; Rabies / сказ; Granulocytic Ehrlichiosis / гранулоцитарний ерліхіоз; Canine Bartonella vinsonii infection / інфекція Bartonella vinsonii у собак; Leptospirosis / лептоспіроз; Canine hepatosoonosis / гепатосооноз собак; Canine skin pythiosis / шкірний пітіоз собак; Nasal cavity aspergillosis / аспергільоз носової порожнини.

2. Endocrine and metabolic diseases /ендокринні та метаболічні хвороби: Diabetes insipidus / нецукровий діабет; Canine Hypotheriosis / гіпотеріоз собак; Canine hypertheriosis / гіпертеріоз собак; Hyperparathyroidism / гіперпаратиріоз; Hypercalcaemia / гіперкальціємія; Insulinoma / інсулінома; Pituitary gland-specific hypercorticoidism/гіпофріз-залежний гіперкортицизм; Pituitary gland-specific hyperadrenocorticoidism / гіпофріз-залежний гіперадренокортицизм; Adrenal tumor/адренальна пухлина; Hyperkalemia / гіперкаліємія; Hypernatremia / гіпернатріємія.

\section{Hematology, oncology and immunology} / гематологія, онкологія та імунологія: Immune mediated trombocytopaenia / імуноопосередкована тромбоцитопенія; Hyperthermia / гіпертермія; Systemic lupus erythematosis / системний червоний вовчак; Willebrand disease / хвороба Віллебранда; Postvaccinal fibrosarcoma / поствакцинальна фрібросаркома.

4. Dermatological diseases / дерматологічні захворювання: Alopecia / алопеція; Itch / свербіж; Dermatophythosis / дерматофрітія; Demodecosis / демодекоз;

5. Diseases of gastrointestinal tract / захворювання шлунково-кишкового тракту: Stomatitis / стоматит; Oesophagitis / езофрагіт; Canine Megaesophagus / мегаезофрагус у собак; Cholangiohepatitis / холангіогепатит.

6. Cardiac and respiratory diseases / кардіореспіраторні захворювання: Supraventricular arrhythmia / суправентрикулярна тахіаритмія; Feline dirofilariasis / дірофріляріоз у кішок; Polyps of air passages / поліпи дихальних шляхів; Tracheae paralysis / колапс трахеї.

7. Diseases of urinary ways / захворювання сечовивідних шляхів: Polyuria / поліурія; Polydipsia / полідипсія; Glomerulonephritis / гломерулонефрит.

8. Diseases of reproductive system / захворювання репродуктивної системи: Hytheriosis / гіпотиріоз; Infertility / безпліддя; Orchitis / opxiт.

9. Neurologic and musculoskeletal disorders / неврологічні і скелетно-м'язові порушення: Canine vegetative dystonia / вегетативна дистонія у собак; Feline convulsive disorder / судомний синдром у собак; Feline Born's disease / хвороба Борна у котів.

\section{Ophthalmological diseases} офтальмологічні захворювання: Epiphora / епіфрора; Dry keratoconjuctivitis / сухий кератокон'юктивіт; Ulcerous keratitis / виразковий кератит; Eyes neoplasia / неоплазія очей.

Другий принцип диференціації термінів на позначення хвороб тварин в англійській мові це - Diseases by types of animals (хвороби за видами тварин). Цей гіперонім представлений хворобами саме окремих видів тварин.

Diseases by types of animals / хвороби за видами тварин:

1. Multiple species diseases / хвороби хатніх тварин: Anthrax / сибірська виразка; Aujeszky disease / хвороба Ауєскі; Leptospirosis / 
лептоспіроз; Rabies / сказ; Trichinellosis / трихінельоз.

2. Cattle diseases / хвороби великої pozamoï худоби: Theileriosis / тейлеріоз; Bovine tuberculosis / туберкульоз жуйних; Bovine babesiosis / бабезіоз жуйних; Bovine brucellosis / бруцельоз жуйних; Dermatophilosis / дерматофільоз; Malignant catarrhal fever / злоякісна катаральна лихоманка.

3. Sheep and goat diseases / хвороби овець та кіз: Contagious agalactia / інфекційна агалактія; Scrapie / свербець; Nairoby sheep disease / найробійська хвороба овець; Contagious caprine peluropneumonia / контагіозна плевропневмонія кіз; Caprine arthritis / артрит кіз.

4. Equine disease / хвороби коней: Contagious equine metritis / контагіозний метрит коней; Dourine / парувальна хвороба; Epizootic lymphangitis / Епізоотичний лімфангіт.

5. Lagomorphs diseases / хвороби зайцеподібних: Tularemia / туляремія; Rabbit haemorrhagic disease / геморагічна хвороба кроликів; Myxomatosis / міксоматоз.

6. Avian diseases / хвороби пmaxis: Avian chlamidiosis / хламідіоз птахів; Fowl pox / пташина віспа; Fowl typhoid / пташиний тиф; Avian tuberculosis / пташиний туберкульоз; Marek's disease / хвороба Марека.

7. Fish diseases / хвороби риб: Spring viraemia of carp / весіння вірусемія коропів; Infectious haemapoietic necrosis / інфеекційний гематопоітичний некроз; Epizootic haematopoietic necrosis / епізоотичний гематопоітичний некроз.

8. Mollusks diseases / хвороби молюсків: Bonamiosis / бонаміоз; Perkinsosis / перкінсоз; Microcytosis / мікроцитоз.

9. Swine diseases / хвороби свиней: Atrophic rhinitis of swine / атрофрічний риніт свиней; Enterovirus encephalomyelitis / ентеровірус

10. Bee diseases / хвороби бджіл: Acariosis of bees / акаріоз бджіл; American foulbrood / американський гнилець; European foulbrood / європейський гнилець; Varroosis / варрооз.

У наведених прикладах визначення не

\section{Список використаних джерел}

1. Вакулик І. І. Сучасні ветеринарномедичні терміни як презентанти анатомічної номенклатури. Науковий вісник Криворізького державного педагогічного університету. Філологічні студії. Кривий Ріг : 2013. №9. С. 66-73.

2. Комарова Л. Н. Эпонимы в ветеринарной медицине на английском языке. XI Международная научно-практическая конференция «Приоритетные направления развития науки и образования». Чебоксары: Изд-во ЧГУ. 2016. С. 12-15.

3. Комарова Л. Н. Истоки ветеринарной терминологии. II Международная научно- тільки конкретизують номінацію певної хвороби, але й вказують на належність її до певного класифікаційного ряду, компонент, який диференціює (вид хвороби) у номінації термінів, має обмежений характер і вказує на відмінну видову ознаку терміна.

Важливо підкреслити, що аналізована родо-видова структура термінів має багаторівневу організацію, що віддзеркалює еволюцію розвитку цієї клінічної галузі ветеринарної медицини. Структурний аналіз ієрархічної організації термінів на позначення хвороб тварин в англійській мові дозволяє не тільки мати уявлення про зміст цієї предметної галузі, а й краще зрозуміти принципи формування галузевої термінології, що має велике значення для лексикографічної i перекладацької практики.

Висновки. Отже, в процесі взаємодії термінів, які розташовуються на різних ієрархічних рівнях, встановлюються стійкі зв'язки під час переходів від одних понять до інших, і відбувається їх взаємопроникнення. Будь-яка ветеринарно-медична класифікація - це ієрархічна структура, що вступає в гіперогіпонімічні відносини термінів, що утворюють великі терміносистеми. Цей тип відношень між одиницями, заснований на родо-видовій концептуальній спільності і $\epsilon$ одним 3 найважливіших принципів структурування знань і організації термінологічного складу терміносистеми «хвороби тварин».

Терміни на позначення хвороб тварин показують взаємозв'язки явищ, процесів, предметів, що відповідають цій сфері роботи лікарів-ветеринарів, i їх впорядкування можна досяги завдяки правильній класифікації реалій, $з$ яких створюються терміни на основі виділення родових i видових явищ. Отже, виражається закономірність участі термінологічних одиниць у сталих системних відношеннях субординації, які характерні для процесів інтеграції або диференціації їх компонентів як на різних, так і на одному рівні їх виявлення.

практическая конференция. «Новое слово в науке: стратегии развития». Чебоксары : Издво ЧГУ. 2017. 1(9). С. 41-44.

4. Лысякова М. В. Гиперо-гипонимическая таксономия в терминоведении. Вестник Российского университета дружбы народов. Серия «Лингвистика», 2006. 8. С. 23-28.

5. Орлов Ф. М. Словарь ветеринарних клинических терминов. Москва : Россельхозиздат. 2018. 367 c.

6. Рожков Ю. Г. Лінгвістичні та екстралінгвістичні чинники формування англомовного термінологічного поля «хвороби тварин». Науковий журнал «Міжнародний 
фрілологічний часопис». 2020. 11 (4). С. 90-96.

7. Рожков Ю. Г. Метафоризація в англомовному термінологічному полі «хвороби тварин» у лінгвокогнітивному аспекті. Вісник Харківського національного університету імені В. Н. Каразіна. Серія «Філологія. 2020. 84. С. 5561.

8. Рожков Ю. Г. Метонімічні транспозиції у термінологічному полі «хвороби тварин». Науковий журнал «Міжнародний фрілологічний часопис». 2020. 11 (1). С. 74-79.

9. Сиротина Е. А. Категории пространства и времени в англоязычной терминологии ветеринарной медицины. Studia Humanitatis. 2020. № 3. URL: http://sthum.ru/sites/st-hum.ru/files/pdf/surotina.pdf

10. Тимкина Ю. Ю. Классификация ветеринарной терминологии в английском языке. Филологические науки. Вопросы теории и практики.Тамбов: Грамота. 2017. 6(1). С. 156-158.

11. Тимкина Ю. Ю. Англоязычные лексикограмматические единицы

области «Ветеринария». Балтийский гуманитарный журнал. Калининград: Ассоциация ПААС. 2019. 2 (19). С. $62-65$.

12. Череповська Т., Бінкевич О. Морфологічні особливості ветеринарної термінології в контексті викладання англійської мови для конкретних цілей. Наукові записки Національного університету «Острозька академія»: серія «Філологія». Острог: Вид-во HaYOA, 2019.5 (73). C. 310-312.

13. Ягенич Л. В. К вопросу о классификации терминологии ветеринарной медицины в современном английском языке. Фундаментальная наука вузам. Москва: Изд-во МПГУ. 2020.6 (22). С. 342-351.

14. Яковлева С. А. Сокращения как лингвистическая особенность ветеринарных терминов (на материале английского языка) Magister Dixit. научно-педагогический журнал Восточной Сибири. 2011. 4. С. 36-40.

\section{References}

1. Cherepovska, T., Binkevych, O. (2019). Morfolohichni osoblyvosti veterynarnoi terminolohii $\mathrm{v}$ konteksti vykladannia anhliiskoi movy dlia konkretnykh tsilei [Morphological peculiarities of veterinary terminology in the context of teaching English for specific purposes]. Scientific proceedings of Ostroh academy: Philology series. Ostroh: Vyd-vo NUOA, 5 (73). 310-312.

2. Komarova, L. N. (2016). Eponimy v veterynarnoi medytsyne na anhlyiskom yazyke [Eponyms in the English veterinary medicine terminology]. XI International scientific and practical conference "Priority direction of science and education development". Cheboksary: Vyd-vo ChHU. 12-15.

3. Komarova, L. N. (2017). Istoky veterynarnoi termynolohyy [Sources of veterinary terminology]. II international scientific and practical conference. "New word in science: strategies of development". Cheboksary : Vyd-vo ChHU, 1(9). 41-44.

4. Lysiakova, M. V. (2006). Hyperohyponymycheskaia taksonomyia $\mathrm{v}$ termynovedenyy [Hyper-hyponymy Taxonomy withing Terminology]. Journal of Peoples' Friendship University of Russia. Linguistics series, 8. 23-28.

5. Orlov, F. M. (2018). Slovar veterynarnykh klinycheskikh termynov. [Dictionary of veterinary clinical terms]. Moscow : Rosselkhozizdat. 367.

6. Rozhkov, Yu. H. (2020). Linguistic and extralinguistic factors in the formation of the English terminological field "animal diseases". Scientific journal "International journal of philology”, 11 (4). 90-96.

7. Rozhkov, Yu. H. (2020). Linguocognitive aspect of metaphorization in the English language terminological field "animal diseases". The Journal of V. N. Karazin Kharkiv National University Series "Philology", 84. 55-61.

8. Rozhkov, Yu. H. (2020). Metonymic transpositions in the terminological field "animal diseases". Scientific journal "International journal of philology", 11 (1). 74-79.

9. Syrotyna, E. A. (2020). Katehoryy prostranstva y vremeny $v$ anhloiazichnoi termynolohyy veterynarnoi medytsyny [Categories of Space and Time in the English Terminology of Veterinary Medicine]. Studia Humanitatis. 2020. No. 3. Extracted from http://st-hum.ru/sites/sthum.ru/files/pdf/surotina.pdf

10. Tymkyna, Yu. Yu. (2019). Anhloiazychnye leksyko-hrammatycheskye edynytsy oblasty «Veterynaryia» [English lexical and grammatical units of veterinary terminology]. Baltic humanitarian journal. Kaliningrad: Assotsyatsyia PAAS, 2 (19). 62-65.

11. Timkina, Yu. Yu. (2017). Klassyfykatsyia veterynarnoi termynolohyy $\mathrm{v}$ anhlyiskom yazyke [Classification of veterinary terminology in the English language]. Philological sciences. Issues of theory and practice. Tambov: Gramota, 6 (1). 156-158.

12. Vakulyk, I. I. (2013). Suchasni veterynarno-medychni terminy yak prezentanty anatomichnoi nomenklatury [Modern medical and veterinarian terms as a presenter of anatomical terminology]. Scientific Bulletin of Kryvyi Rih State Pedagogical University. Philological Studies. Kryvyi Rih, 9. 66-73.

13. Yahenych, L. V. (2020). K voprosu o klassyfykatsyy termynolohyy veterynarnoi medytsyny $\mathrm{v}$ sovremennom anhlyiskom yazyke [On the classification of veterinary medical terminology in modern English]. Fundamental sciences to universities. Moscow: Vyd-vo MPHU, 6 (22). 342-351.

14. Yakovleva, S. A. (2011). Sokrashchenyia kak lynhvystycheskaia osobennost veterynarnykh 
terminov (na materyale anhlyiskoho yazyka). [Abbreviations as a linguistic peculiarity of veterinary terms (based on English language)].
Magister Dixit. Scientific and pedagogical journal of Eastern Siberia, 4. 36-40.

\title{
HYPER-HYPONYMIC RELATIONS IN THE ENGLISH TERMS TO DENOTE ANIMAL DISEASES Yu. H. Rozhkov
}

\begin{abstract}
The concepts of each subject area, which are interconnected, form a conceptual system of a particular science. The relationship and dependence of special concepts is often manifested in hyperhyponymic relations. Structures built on the relations of hyper-hyponymy between professional concepts are a complex framework of terminology. The interrelationships between individual language units and between their associations depend on the relation between terms. The study of the processes of formation of hyperhyponymic relations is one of the central problems of cognitive semantics, as categorization is directly related to the global problem of theoretical linguistics in the ratio of cognitive and linguistic structures.

The purpose of the article is to study the specifics of the hierarchical structure of terms to denote animal diseases on the basis of hyper-hyponymic relations and to determine a set of language tools for their expression.

Materials and methods of research. Component and distributive analysis were used to study the structure of terms. To establish the semantic connections of words, lexicographic analysis is used, which is based on the principle of using dictionary interpretations, which in most cases are a reliable sources of thematic groups of terminological units. To identify systemic linguistic relations in the studied terminology, we use distributive analysis and the method of semantic oppositions.

Results of the research. The construction of a hierarchical structure of terms to denote animal diseases was carried out by analyzing the relationship between the term denoting a common generic concept and a term that reflects the variants of the same concept.

In the terminology to denote animal diseases, two directions of term formation were distinguished: differentiation by the place of lesion and by species of animals. The hyperonym diseases by location is generic to other terms in its group: endocrine and metabolic diseases; hematology, oncology and immunology; dermatological diseases; diseases of the gastrointestinal tract; cardiac and respiratory diseases; diseases of urinary tracts; diseases of reproductive system; neurologic and musculoskeletal disorders; ophthalmological diseases.

The second principle of differentiation of terms to denote animal diseases in English is diseases by animal species. This hyperonym is represented by diseases of certain species of animals.

It is established that the analyzed hyper-hyponymic structure of terms has a multilevel organization, which reflects the evolution of the development of this clinical branch of veterinary medicine. Structural analysis of the hierarchical organization of terms to denote animal diseases in English allows not only to have an idea of the content of this subject area, but also to better understand the principles of terminology structure, which is important for lexicographic and translation practice.

Conclusions. Terms to denote animal diseases show the relationship of phenomena, processes, objects that correspond to this area of work of veterinarians, and their ordering can be achieved through the correct classification of realities, which create terms based on the selection of hyperonyms and hyponyms. Thus, the regularity of the participation of terminological units in the constant systemic relations of subordination, which are characteristic of the processes of integration or differentiation of their components both at different and at the same levels of their detection, is expressed.
\end{abstract}

Keywords: hypero-hyponymic relations, terminology, animal diseases, veterinary medicine, structural analysis, semantic analysis. 